\title{
Microstructure and Properties of Different Preforms for Cartridge Case Production
}

\author{
Nada Ilić ${ }^{1)}$ \\ Ljubica Radović ${ }^{1)}$ \\ Milorad Stanić ${ }^{2)}$
}

\begin{abstract}
The aim of this work was to evaluate properties of two different preforms for production of $23 \mathrm{~mm}$ steel cartridge case. Full scale testing, including chemical composition, macrostructure, microstructure and hardness were used. It was assumed that both metallurgical properties, presence of slag and coarse inclusions, as well as process parameters affected those defects that appeared during production of cartridge case from ČR2. In the macrostructure and microstructure of the C10E steel bars, different defects were observed which may have decrease formability during deformation.
\end{abstract}

Key words: steel, cartridge case, $23 \mathrm{~mm}$ caliber, microstructure, chemical composition, slag, production technology.

\section{Introduction}

$\mathrm{T}$

HE most of the steel cartridge cases are produced of low carbon steel. Plate or rod materials as a preform are used [1]. Low carbon steel shave moderate strength and hardness in the as-rolled or extruded condition and good formability in the annealed condition. It can be hardened and strengthened by cold work. The formability of these steels allows high reduction of the wall thickness during manufacture of a cartridge case. It also has fair machinability and good weldability [2].

During production of cartridge cases various kinds of defects can occur, related either to material (microstructure, impurities) or technology parameters (unadequate load, temperature, cooling rate, lubricants etc.). These defects can be deleterious to the manufacture of a quality cartridge case [3-6].

The main objective of this paper is to characterize two steels for the manufacture of $23 \mathrm{~mm}$ cartridge case and reveal the cause of defects during theirs production.

\section{Experimental work}

\section{Material and technology}

The materials used in this study were C10E and ČR2 steels, used for the manufacture of the cartridge case of $23 \mathrm{~mm}$. Steel C10E was supplied as bars $(\phi 40 \mathrm{~mm})$ and steel ČR2 was supplied as cups. During manufacturing process, when a preform (blank $\phi 58.2 \times 13 \mathrm{~mm}$ ) was formed into a cup shape with wall thinning $\left(1^{\text {st }}\right.$ drawing $)$, in some specimens defects were observed. For this investigation two bars and two cups with surface defects supplied.

The nominal chemical composition of the used steels $\mathrm{C} 10 \mathrm{E}$ and $\breve{C} 22$ are given in Table 1 .
Table 1. Nominal chemical composition of the C10E steel and ČR2

\begin{tabular}{|c|c|c||}
\hline Mass. \% & C10E steel & ČR2 steel \\
\hline \hline According to & SRPS EN 10084 & SORS 1648 \\
\hline $\mathrm{C}$ & $0.07-0.13$ & $0.09-0.13$ \\
$\mathrm{Si}$ & Max 0.40 & Max 0.13 \\
$\mathrm{Mn}$ & $0.30-0.60$ & $0.30-0.50$ \\
$\mathrm{P}$ & Max 0.035 & Max 0.025 \\
$\mathrm{S}$ & 0.035 & Max 0.025 \\
$\mathrm{Cr}$ & $/$ & Max 0.20 \\
$\mathrm{Ni}$ & $/$ & Max 0.15 \\
$\mathrm{Cu}$ & $/$ & Max 0.20 \\
$\mathrm{Al}$ & $/$ & $0.03-0.07$ \\
\hline
\end{tabular}

\section{Methods}

Visual observation performed by naked eye and stereo microscope Leica 205A.

Dimension measurement was performed using a comparator.

The chemical composition was analyzed by the Optical Energy Spectrometer (OES) Belec Compact Port.

Hardness was measured by the Brinell method (HB 2,5/187,5), according to SRPS EN ISO 6506-1.

A transverse cross section of the bars and cups was taken and prepared for microstructure examination.

Macrostructure was revealed after etching in $50 \%$ solution of $\mathrm{HCl}$ at $70-80^{\circ} \mathrm{C}$ after $60 \mathrm{~min}$, according to SORS 1710 .

The content of the inclusions estimated according to SRPS EN 10247 (Annex A).

Microstructure was examined on the cross section of the bars and longitudinal section of the cups, using light microscopy (LM) and 3\% nitalas etchant.

Energy dispersive X-ray spectroscopy (EDS) was used in conjunction with SEM to characterize the composition of the chosen area.

\footnotetext{
1) Military Technical Institute (VTI), Ratka Resanovića 1, 11132 Belgrade, SERBIA

2) Sloboda Company d.o.o, Ratka Mitrovića bb, 32000 Čačak, SERBIA

Correspondence to: Nada Ilić; e-mail: nadalic67@vti.vs.rs
} 


\section{Results and discussion}

Visual examination and dimension measurement

The specimens of the cups after $1^{\text {st }}$ drawing are shown in Fig.1. The surface defects, such as wavelength on the top of the wall, as well as notch in circumference in the inner side of the cups, were observed. At higher magnification these defect are shown in Fig.2.

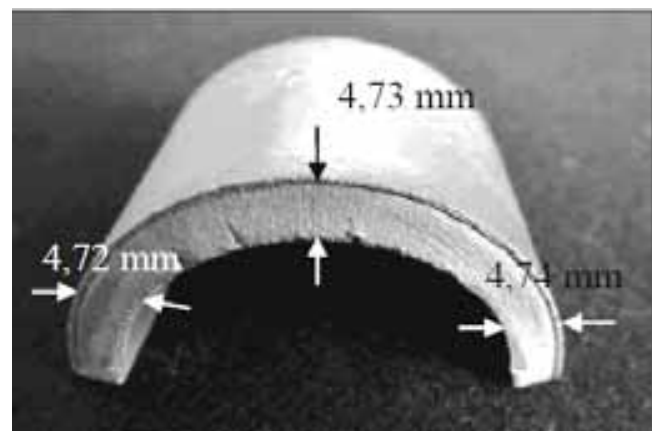

a)

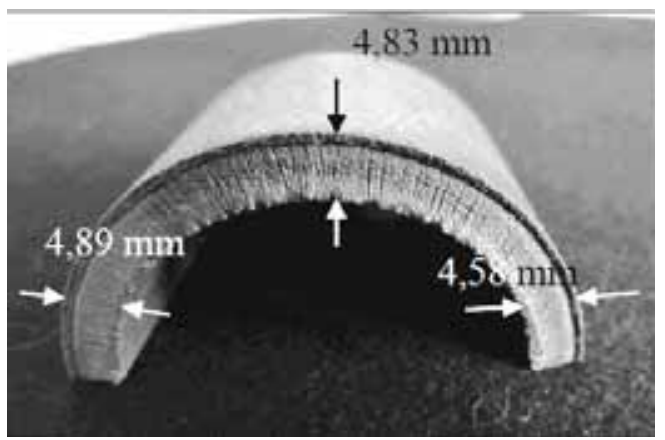

b)

Figure 1. The wall thickness: a) cup 1; b) cup 2 .

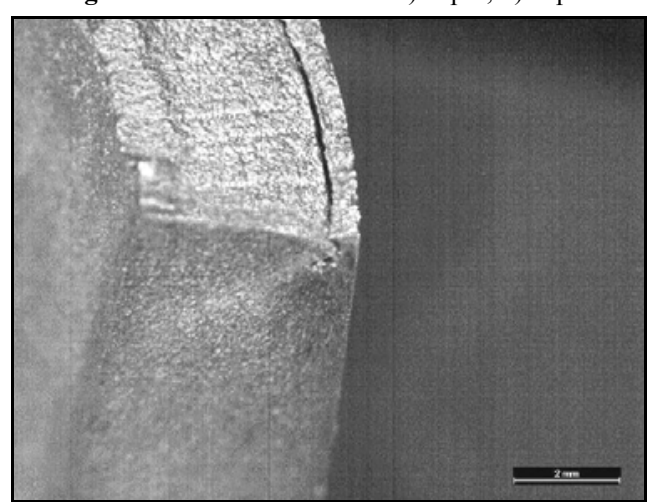

a)

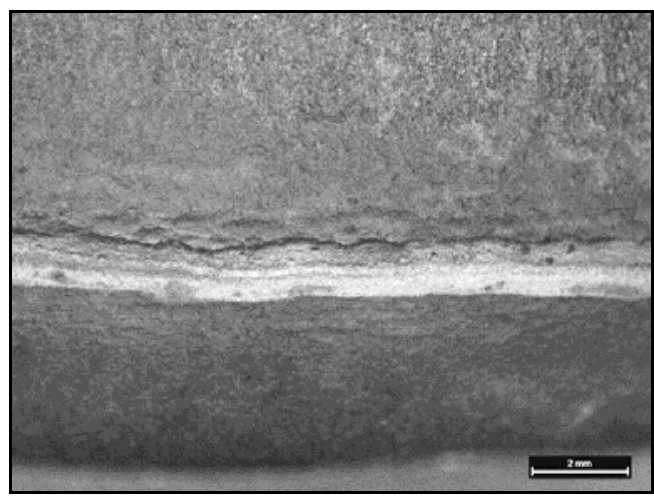

b)

Figure 2. Defects of the cup 2: a) on the top of the wall; b) notch in the inner side.

The results of dimension measurements of the cups revealed the difference in the wall thickness on the circumference, as designated in Fig.1 (tolerance $\pm 0.1 \mathrm{~mm}$ ).
Larger dimension deviation was found on the cup 2.

All these defects suggest non-regular material flow during drawing. This can be attributed to larger load, due to contact between tool and workpiece or poor lubrication, as well as unsupported or noncentric tools.

\section{Chemical composition}

The chemical composition of the bars and cups tested in this work are given in Table 2. Results showed that chemical composition of the bars is according to chemical composition C10E steel (SRPS EN 10084). However, the composition of the cup 2 does not correspond to the requirements of the standard for the steel ČR2 (SORS 1648). The content of carbon of 0.55 mas. \% is lower than required (0.09-0.13 mas. \%).

\section{Hardness}

Results of the hardness measurements of the tested specimens are given in Table 3 . It was found that the hardness of the bars correspond to annealed $\mathrm{C} 10 \mathrm{E}$ steel according to requirements of standard SRPS EN 10084. It is assumed that higher values of hardness in cup 1 and cup 2 are due to cold plastic deformation.

Table 2. Chemical composition of the tested C10E steel and ČR2

\begin{tabular}{|c|c|c|c|c||}
\hline \multirow{2}{*}{ Mass. \% } & \multicolumn{2}{|c|}{ C10E steel } & \multicolumn{2}{c|}{ CR2 steel } \\
\cline { 2 - 5 } & Bar 1 & Bar 2 & Cup 1 & Cup 2 \\
\hline \hline$C$ & 0,089 & 0,092 & 0,10 & 0,055 \\
$S i$ & 0,094 & 0,094 & 0,049 & 0,003 \\
$M n$ & 0,39 & 0,39 & 0,33 & 0,37 \\
$P$ & 0,006 & 0,007 & 0,004 & 0,004 \\
$S$ & $<0,001$ & $<0,001$ & $<0,001$ & $<0,001$ \\
$C r$ & 0,086 & 0,086 & 0,132 & 0,011 \\
$N i$ & 0,083 & 0,083 & 0,095 & 0,029 \\
$C u$ & 0,18 & 1,18 & 0,17 & $<0,001$ \\
$A l$ & 0,012 & 0,012 & 0,021 & 0,030 \\
\hline
\end{tabular}

Table 3. Hardness of the bars and cups, HB

\begin{tabular}{|c|c|c|c|}
\hline Bar 1 & Bar 2 & Cup 1 & Cup 2 \\
\hline \hline 120 & 118 & 182 & 179 \\
\hline
\end{tabular}

\section{Macrostructure}

In the macrostructure of the bar 1 defects type $\mathrm{D}$, intensity D1, observed (Fig.3a), while in cup 2 defects type A, i.e. A1. The macrostructure of the cups is shown in Fig.4. The regular, continuous material flow in the cup wall observed in cup 1 (Fig.3a), while in the inner side of the cup 2, in transition zone between bottom and wall side, the notch in circumferential is visible. Also, at the same specimen, along the wall, close to outside, cracks are observed. At higher magnification the notch, where stretching of the material occurred, is shown in Fig.5a and cracks and voids in bottom in Fig.5b.

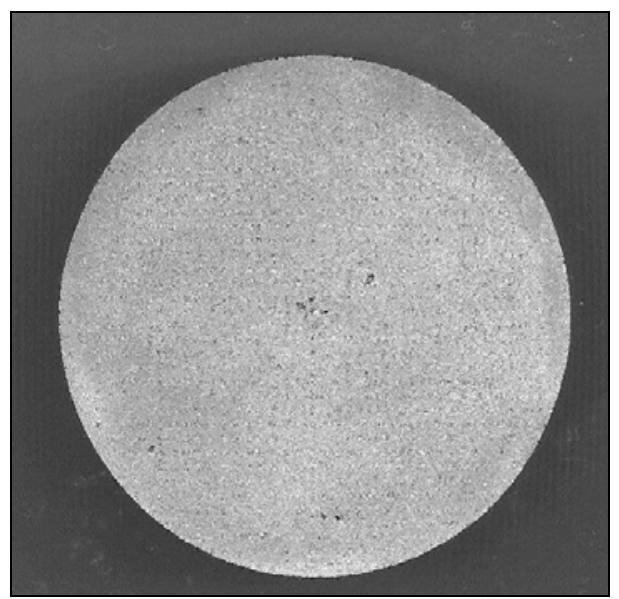

a) 


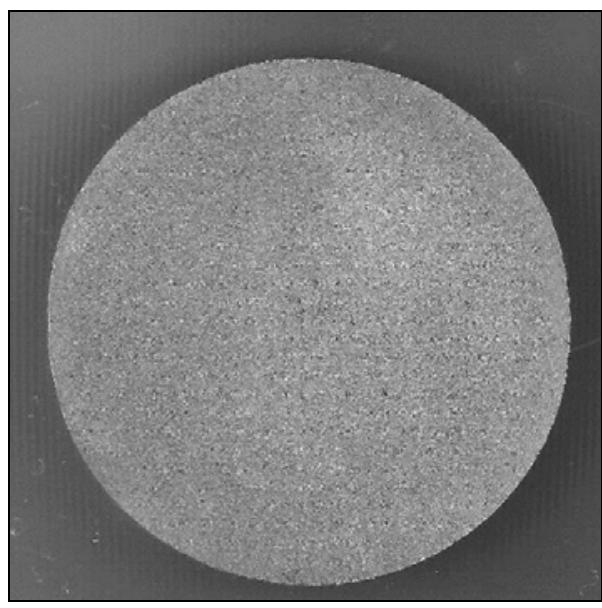

b)

Figure 3. Macrostructure of the bars: a) bar 1; b) bar 2.

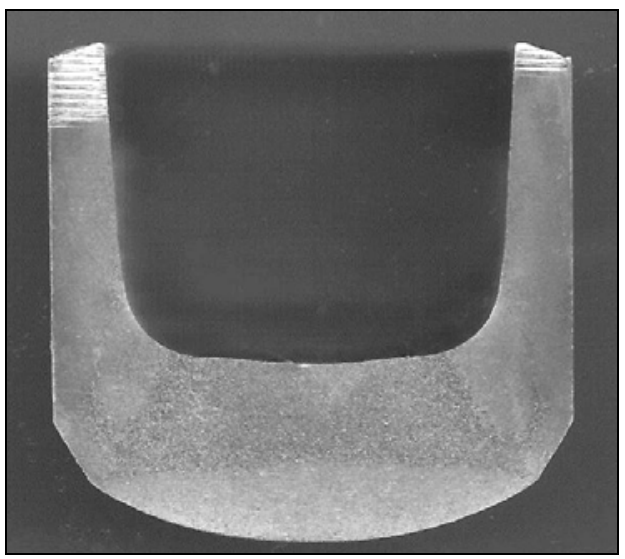

a)

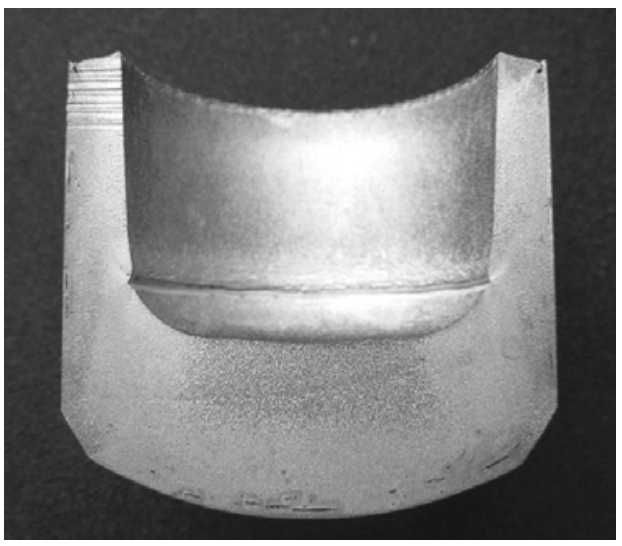

b)

Figure 4. Macrostructure of the cups: a) cup 1; b) cup 2.

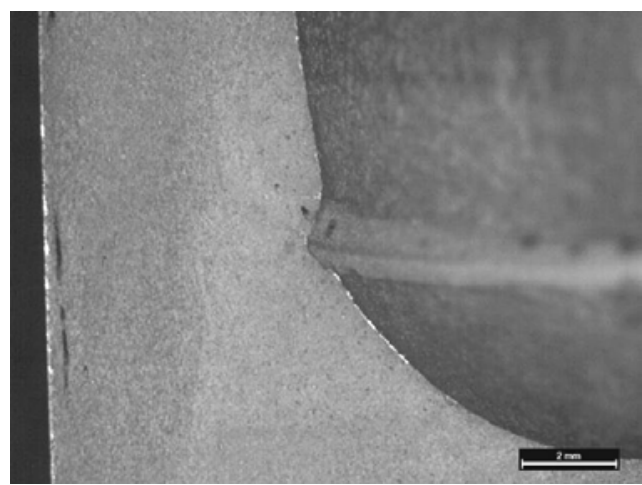

a)

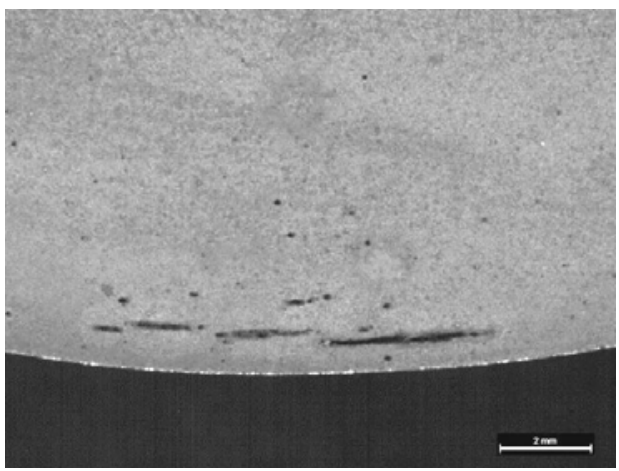

b)

Figure 5. Defects on the cross section of the cups 2: a) notch in the transition wall/bottom; b) cracks and voids in bottom.

\section{Microstructure}

Microstructure of the bars is ferrite-perlite with small grains. Grains are poligonal in the center and towards outside of the bar (Fig.6a), but between these area banded microstructure was observed. (Fig.6b).
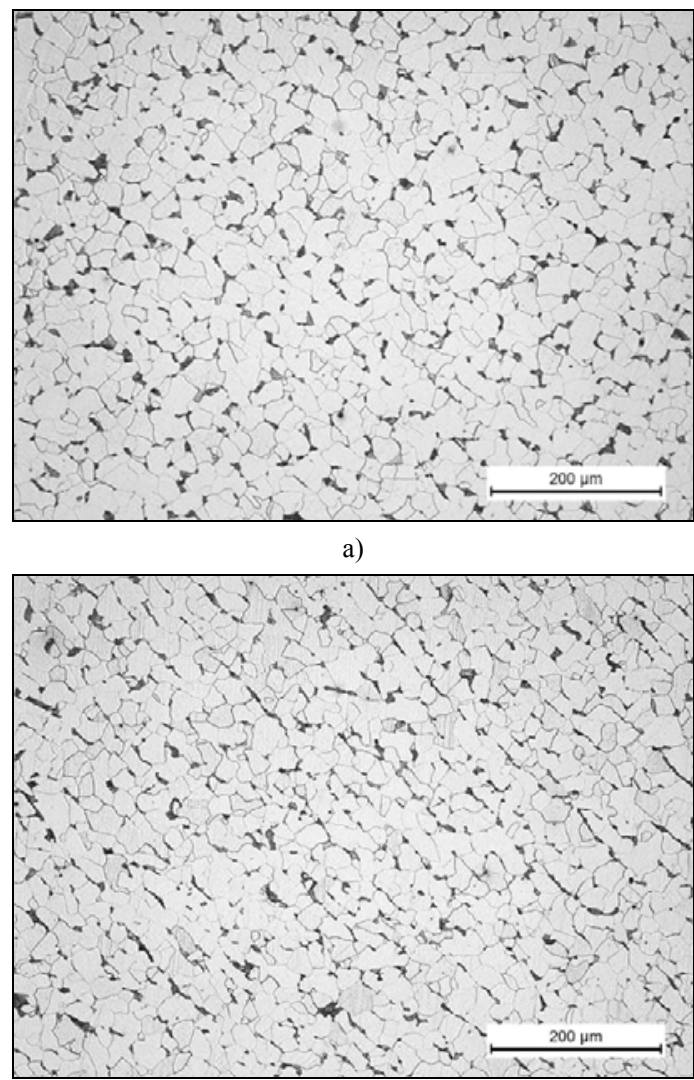

b)

Figure 6. Microstructure of the bar: a) in the center; b) $2 \mathrm{~mm}$ from the outside surface.

Microstructure of the cup material is ferrite-perlite with spheroidized perlite. This microstructure is expected after applied thermo mechanical treatment of the ČR2 steel. On the other hand, a large longitudinal voids in the vicinity of outside surface of the cup 2 (app. $600 \mu \mathrm{m}$ ) were visible. The voids extend from the top to the bottom. Typical appearance of the voids is shown in Figures 7a-c.

The origin of these voids can be related to orientation of grains in the vicinity of the voids and material flow in the tools during plastic deformation. During plastic deformation, on the top of cup wall, large "open" voids form, as shown in Fig.7a. As deformation proceeded the voids become "closed" 
and elongated. This is supported by local microstructure, i.e. similar material flow around the voids (Fig.7b). These defects, observed in the macrostructure (Fig.5b) are caused by initial defects which were present in the preform.

\section{EDS analysis}

Light optical microscopy revealed the presence of coarse inclusions in the microstructure of the bars (Fig.8). It was found that they are mostly type globular oxide, group ED, type $\delta$. Some of them were over $40 \mu \mathrm{m}$. EDS analysis gave their composition (Fig.9).

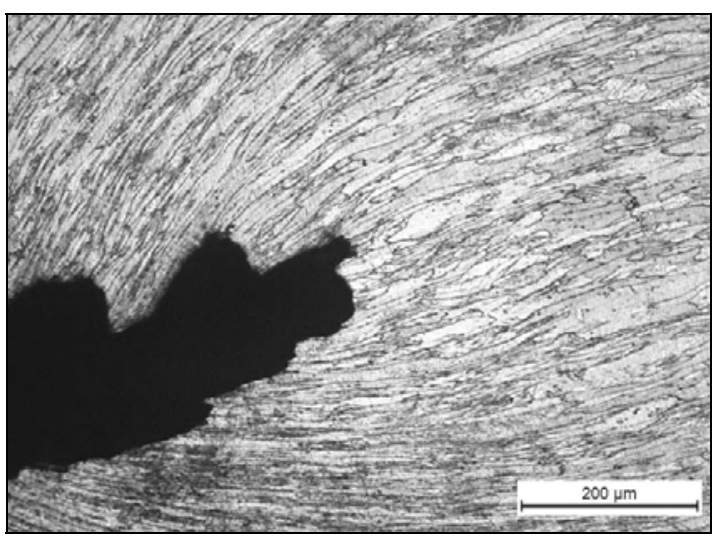

a)

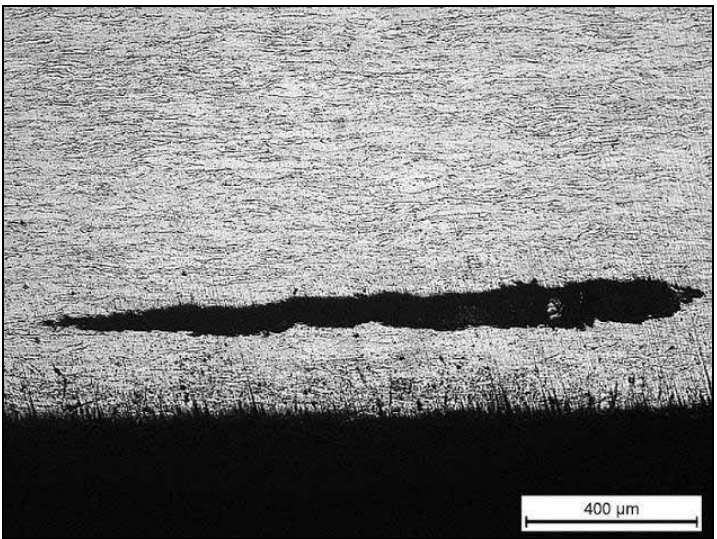

b)

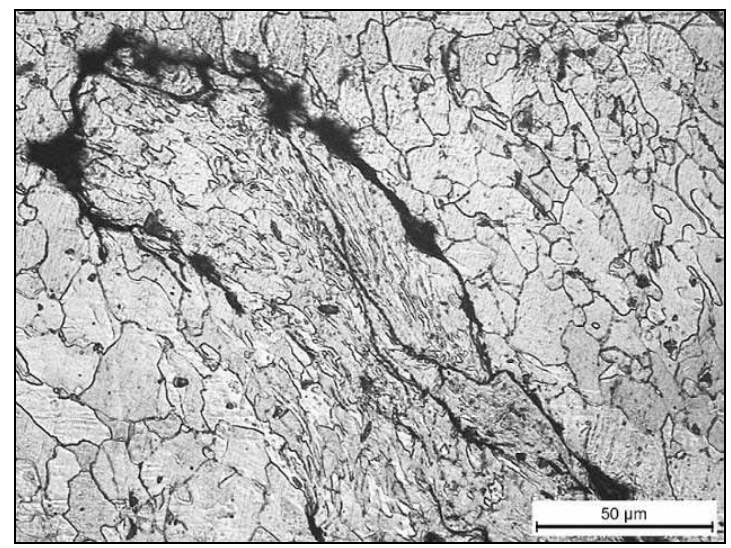

c)

Figure 7. Defects in the cup 2: a) at top of the wall; b), c) on the bottom.

Also, large content of different size inclusions, as shown in Fig.10, is observed. It was found that their composition (Fig.11) correspond to slug composition [7]. The presences of such nonmetallic oxides inclusions, as alumina and calciaalumina, or slug, have negative effect on formability, mechanical properties and generate many defects in the steel products [7-8].

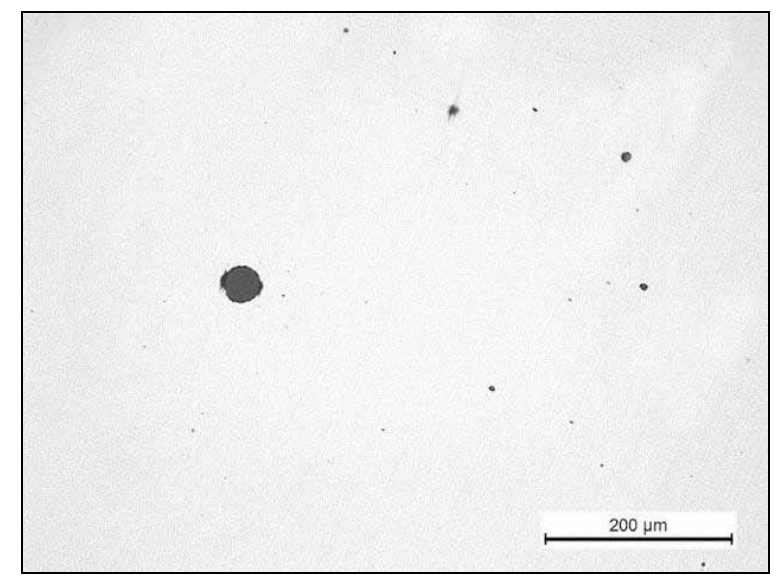

Figure 8. Oxide inclusions in the bar (LM).
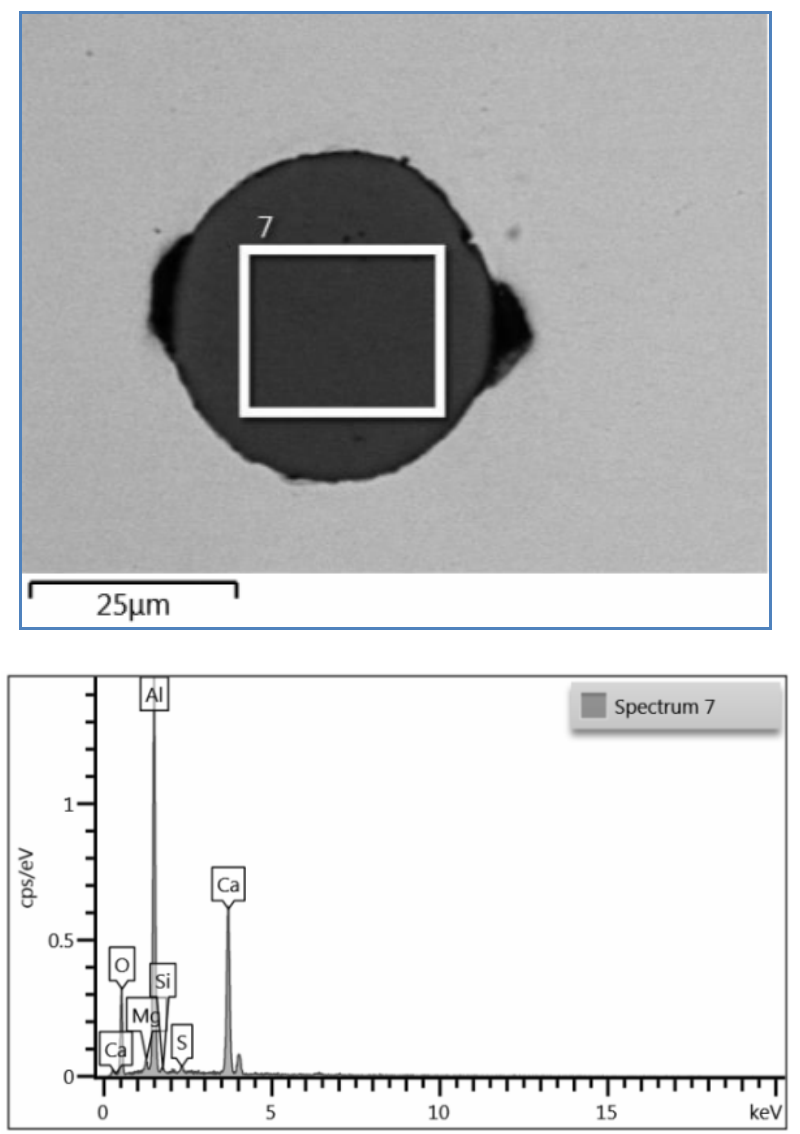

Figure 9. EDS analysis of the oxide inclusions: oxide inclusion and corresponding spectra.

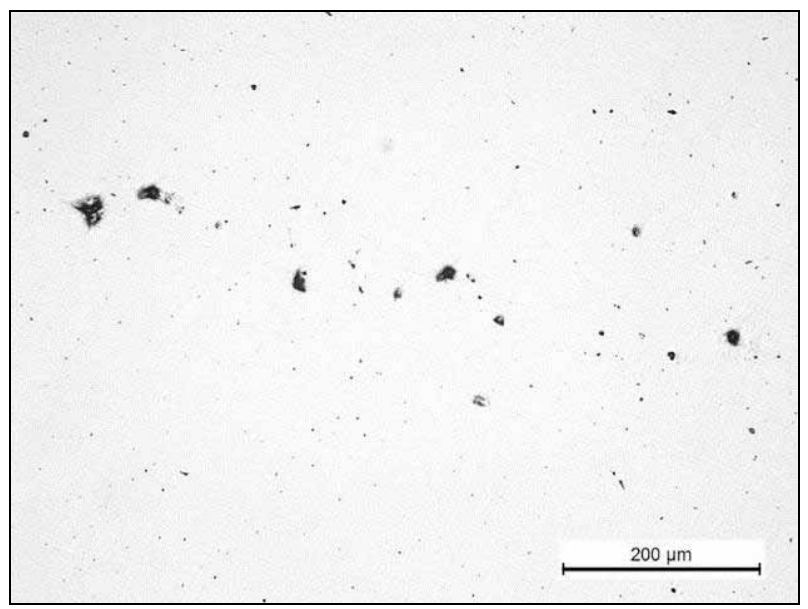

Figure 10. Slug inclusions in the bar (SM). 

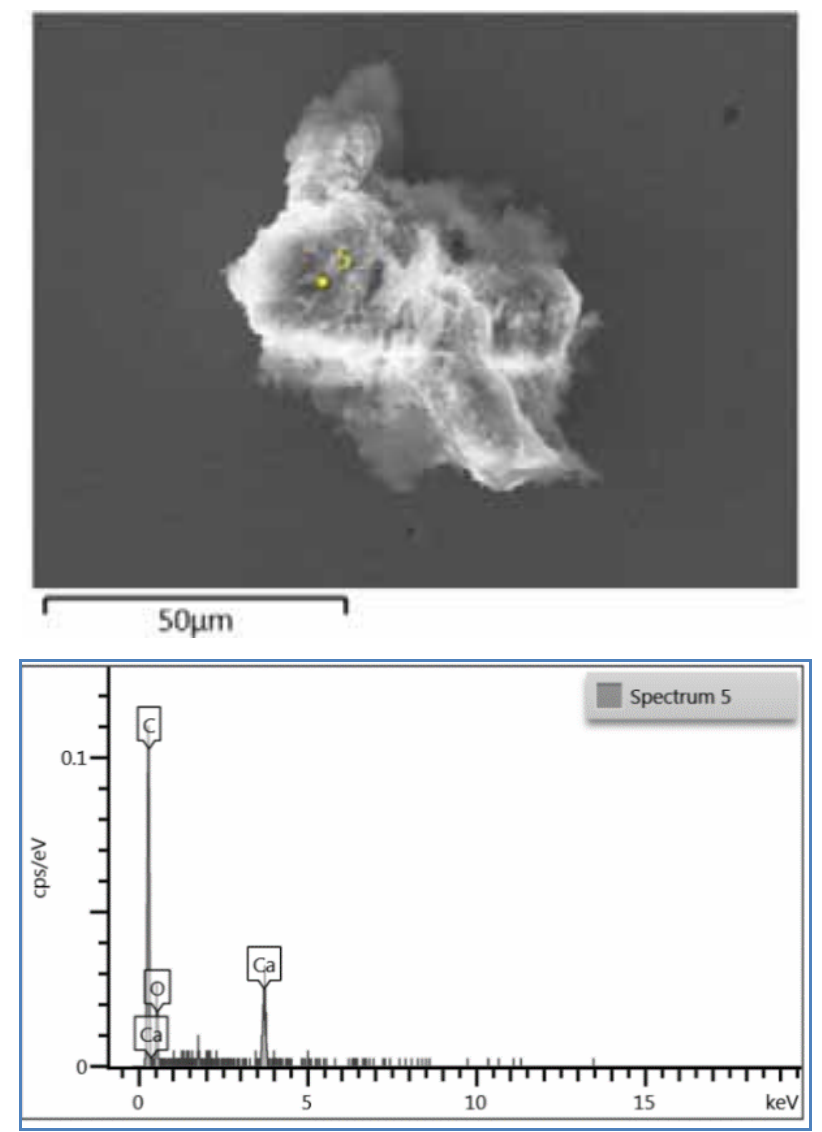

Figure 11. EDS analysis of the slag inclusions: slag inclusion and corresponding spectra.

\section{Conclusion}

The chemical composition and hardness of the tested bars correspond to annealed C10E steel according to SRPS EN 10084 standard. The chemical composition of one of the tested cups (cup 2) does not correspond to the requirements of the standard for the steel ČR2 (SORS 1648).
Macrostructure examination revealed different defects in the tested specimens. In the bars, inclusions series D, D1 intensity, as well as central defects series A, A1 intensity, according to SORS 1710, were observed. In the cup 2 voids and cracks are present, and unregular material flow during plastic deformation occured.

In the microstructure of bars, large content of coarse inclusions, most globular oxides and slugs were found.

\section{References}

[1] BREY,R.J., HAVRON,L.A.: Development of $30 \mathrm{~mm}$ thinwall steel cartridge case, Contractor report arccd-CR-93005, U.S. Army armament research, development and engineering center, New Jersey, USA, 1993.

[2] ASM Metals Handbook, Vol. 1, Properties and Selection: Irons, Steels, and High-Performance Alloys, Metals Park, Ohio, USA, 1979.

[3] ABO-ELKHAIR,M.S.: Failure Analysis of Cartridge Cases Due to Manufacturing Stresses or Due to Fire under Action ofInternal Loading, IJMSE, 2013, Vol.3, No.1, pp.43-49.

[4] Research and Development of Materiel, Engineering Design Handbook, Ammunition SeriesSection 6, Manufacture of Metal Components, of Artillery Ammunition, Headquarters United States Army, Material Command Washington, D. C. 20315, 1964.

[5] AMCP 706-249, Section 6, Manufacture of Metallic Components of Artillery Ammunition, forming part of the Ammunition Series of the Army Materiel Command Engineering Design Handbook Series, US Army, 1964.

[6] EDOSSA,S.K., SINGH,A.P.: Reducing the defect rate of finalproducts through spc tools: a case study, on ammunition cartridge productionfactory, International Journal of Mechanical Engineering and Technology (IJMET), 2016, Vol.7, No.6, pp. 296-308.

[7] HERRING,D.H.: Steel Cleanliness: Inclusions in Steel, 2009, Industrialheating.com, http://www.heat-treat-doctor.com.

[8] ZHANG,L., THOMAS,B.G.: Evaluation and control of steel cleanliness - review, 85th Steelmaking Conference Proceedings, ISSAIME, Warrendale, PA, 2002, pp. 431-452.

\title{
Mikrostrukture i osobine različitih pripremaka za izradu čeličnih čaura
}

Cilj ovog rada bio je da se izvrši karakterizacija pripremka za izradu čaura $23 \mathrm{~mm}$ od dva različita čelika. Izvršeno je ispitivanje hemijskog sastava, makrostrukture, mikrostrukture i tvrdoće. Utvrđeno je da su metalurške osobine, prisustvo šljake, grubi uključci, kao i procesni parametri, uticali na pojavu grešaka i loma tokom proizvodnje čaure od čelika ČR2. U makro i mikrostrukturi šipki od čelika $\mathrm{C} 10 \mathrm{E}$ su takođe, utvrđene različite greške koje su smanjile sposobnost oblikovanja pri deformaciji.

\section{Микроструктуры и свойства различных подготовок к изготовлению гильз из стали}

\begin{abstract}
Целью данной работы было охарактеризовать подготовку к изготовлению 23 мм гильз из двух разных сталей. Химический состав, макроструктура и твёрдость были проверены. Выяснилось, что металлургические свойства, наличие шлака, грубые включения, а также и параметры процесса влияли на возникновение разломов, трещин и стружки при производстве гильз из стали ЧР2. В макроструктуре и в микроструктуре стальных стержней С10Е также были выявлены различные ошибки, которые снизили способность к формированию во время деформации.
\end{abstract}




\title{
Microstructures et caractéristiques de différentes pièces pour la fabrication des douilles en acier
}

\begin{abstract}
Le but de ce travail était de faire une caractérisation de la pièce pour la fabrication des douilles de $23 \mathrm{~mm}$ en deux sortes différentes d'acier. On a effectué l'examen de la composition chimique, de la microstructure et de la dureté. On a constaté que les caractéristiques métallurgiques, la présence de mâchefer, des branchements rudes ainsi que les paramètres du processus font influence sur l'apparition des erreurs et des fractures lors de la fabrication de la douille en acier ČR2. Dans les macro et micro structures des barres en acier C10E on a constaté aussi les différents défauts qui diminuent la capacité de formation au cours de la déformation.
\end{abstract}

Mots clés: acier, douille, calibre 23 mm, microstructure, composition chimique, mâchefer, technologie de fabrication. 